\title{
STRATEGIC DECISION-MAKING SUPPORTED BY TRADITIONAL FINANCIAL INDICATORS
}

\author{
Zoltán Musinszki, Gábor Béla Süveges* \\ Institute of Accounting and Finance, Faculty of Economics, University of Miskolc, Miskolc, \\ Hungary \\ musinszki.zoltan@uni-miskolc.hu \\ suveges.gabor@uni-miskolc.hu
}

\begin{abstract}
Traditional financial indicators calculated from financial statements cannot provide adequate information for the management, do not support strategic decisions. The reason for this is the methodology used in producing financial statements and the operational logic of financial accounting. Financial accounting thinks in terms of business year that is 12 months. It deals with events of the past, more accurately, with so called economic activities. Financial accounting evaluates such economic activities in terms of monetary processes, which means that the traditional financial indicators have their limits in application. Could it mean that traditional financial indicators cannot be used in the long-term strategic decision making? In our study we point out two connections between financial indicators and strategic decision making. Firstly, we focus on financial indicators used in supported strategic decision making, in strategic indicator systems. Secondly, we focus on cases in which financial indicators complement the methods of strategic decision making, add something to the tools available in strategic management.
\end{abstract}

Keywords: financial statement, financial indicators, strategy, strategic decision making, Balanced Scorecard.

JEL classification: C80; G30.

\section{Introduction}

Financial statements, their content and layout are regulated by legal norms. Such norms ensure that financial statements provide information for all stakeholders on the assets, liabilities, equity, revenues, expenditures, financial results, cash-flow, financial performance, changes in equity of organizations falling under the legislation. This information shall be made available and applicable in making economic decisions. Financial statements ensure that financial accounting is an important - but not exclusive - provider of information for the players of the market. According to the legislators' concept, nowadays financial accounting shall provide useful and reliable information mostly for the players of the market (i.e. for the seller and the buyer, and/or for the owner, the representative of the owner, the investor - that is external stakeholders).

The primary purpose of the Financial Statements is to inform stakeholders. At the same time it is questionable how the Financial Statements are able to help the internal stakeholders within the company, especially in case when the long-term work of internal stakeholders has to be supported.

This paper is looking for an answer to the question of whether the Financial Statements and financial indicators derived from them appear in the methods of strategic decision making. Regarding the methodology, it follows the following logic: The second chapter presents the

\footnotetext{
* Corresponding author: Gábor Béla Süveges
} 
theoretical background of the Financial Statements and Financial indicators calculated from the statements. The third chapter firstly introduces how financial indicators are included in the support of strategic decision making with particular emphasis on the role of BS and secondly it looks for the supporting methods that of strategic decision making. Based on the most important international literature the paper gives answers to the research questions.

\section{Source and critic of traditional financial indicators}

Financial statements are a structured representation of the financial position and financial performance of an entity. The objective of general purpose financial statements is to provide information about the financial position, financial performance and cash flows of an entity that is useful to a wide range of users in making economic decisions. Financial statements also show the results of management's stewardship of the resources entrusted to it. To meet this objective, financial statements provide information about an entity's:

- assets;

- liabilities;

- equity;

- income and expenses, including gains and losses;

- other changes in equity; and

- cash flows.

This information, along with other information in the notes, assists users of financial statements in predicting the entity's future cash flows and, in particular, their timing and certainty" (International Accounting Standard 1: 7. par(hereinafter IAS1)).

As the demand for information by some stakeholders only partially aligns with the information given readily by the business entity; the legislators, in order to resolve the conflict of interest, formulated guidelines and/or rules.

The IAS 1. Presentation of Financial Statements sets out the requirements for the components of financial statements as follows:

- balance sheet,

- income statement,

- statement of changes in equity

- cash flow statement,

- Notes (comprising a summary of significant accounting policies and other explanatory notes) (IAS1, 8. par.).

Balance sheet is a statement of financial position at the end of a period (end of the business year) in terms of assets and financing (liabilities and ownership equity). Current and non-current assets shall be separated just like current and non-current liabilities. IAS1 does not prescribe the format of the statement of financial position but regulates the minimum information that shall be included. Besides the minimum, entities may add additional line items, headings and subtotals if they are relevant to the understanding of the financial situation of the entity.

The income statement presents the results at the end of a period of activity. It presents information on the profit and loss and other comprehensive income. Similar to the balance sheet, the income statement does not have a standardized format. The IAS1 prescribes the minimum line items and it gives the entity a choice in presentation.

Statement of changes in equity, analysis of other comprehensive income and statement of cash flows are also required by the IAS 1 standard.

These statements are not enough to inform stakeholders though. Further numerical and verbal additions are required. These additions make up the notes, the content of which is regulated by the standard in the forms of general and specific rules (e.g. the notes must 
present information on the specific accounting policies used) and also by the entity that decides upon other disclosures it wishes to present.

Traditional financial indicators provide information about property, financial and profitability situation. We can get a picture including:

- Structure of assets and liabilities,

- Asset efficiency,

- Debts,

- Liquidity,

- Profitability compared to various projection bases.

Traditional financial indicators used by organizations for performance evaluation are not able to provide adequate information to management. This is mainly due to financial accounting itself. Financial Accounting:

- Thinks in business years, typically one year,

- Processes most of the events that have taken place - more precisely, some of the events, so-called economic events,

- Evaluate events in monetary terms,

- It is a closed system.

Accordingly, the limitations of traditional financial indicators used in performance measurement are as follows:

- traditional financial indicators reflect on the past, they are not connected to the future, to the strategy of the entity,

- their focus is short-term so they do not support long-term strategic goals,

- because of their fiscal nature they cannot reflect qualitative factors, even though performance analysis requires the review of both quantitative and qualitative elements

- as traditional financial indicators take the effect of past activities and consumer decisions into account, they are not fitting to prevent problems

- they are not of diagnostic nature, which means they reveal problems but not their causes (Demény and Musinszki, 2016; Fenyves et al., 2018).

\section{The role of financial indicators in supporting strategic}

\subsection{The inclusion of financial indicators in methods supporting strategic decisions} In today's highly competitive environment the financial indicators alone are not able to give direction for the future; typically they can give a view about some actions of the past, and so are retrospective, post factum indicators. Based on theoretical and practical experience, both financial and non- financial indicators need to be reflected in the benchmark. 


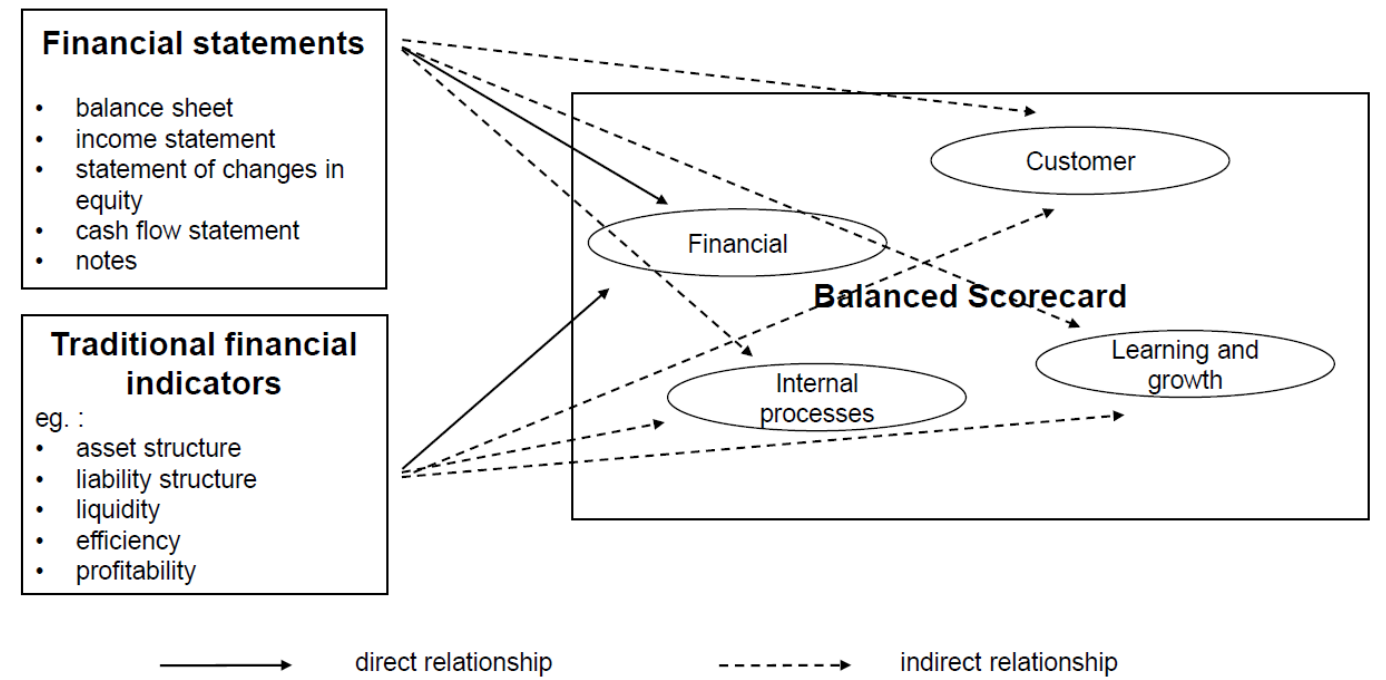

Figure 1: Relationship between financial statements and Balanced Scorecard Source: Own edition

The balance between them has to be created and they have to be united in a complex indicator system. This is achieved by the Balanced Scorecard (BSC). The BSC is a balanced, performance indicators-based strategic evaluation system. Balanced as:

- it is trying to create a balance of the viewpoints in it,

- it takes into consideration objective, easy to quantify outcome indicators and also subjective performance indicators slightly depending on an individual opinion.

- it creates balance between the short- and long term purposes.

Performance indicators-based and strategic: cause the strategic aims and initiatives are translated to actual index-numbers by BSC, and as a result of this method the strategy takes place.

Evaluation system: because the target value is continually matched with the real achievement by BSC, the feedback can be feasible based on the gap analysis.

The viewpoints of the basic model are the financial, the customer, the internal processes, and the learning and growth viewpoint (Kaplan and Norton, 1992).

However, the basic model was not regarded as a definite model by the model creators. Over the last two decades different types of the basic model have been revealed taking different factors into consideration. The range of the stakeholders has expanded; the supplier, the future, social responsibility and sustainability have become independent viewpoints (Butler et al., 2011; Hágen and Borsós, 2015; Maltz et al., 2003; Veresné, 2013).

In time, all these thoughts have gained ground in legal norms as well. In accordance to the 2013/34/EU directive, besides financial processes of the entity, financial statements shall also reflect environmental and social aspects of business processes. The foremost aim of the directive is to ensure sustainability, to present environmental and social aspects of activities and performance. Namely, in order to achieve a sustainable global economy long-term profitability shall go hand in hand with social justice and environmental protection (Demény and Musinszki, 2016; Molnár, 2016; Molnár and Tumik, 2017).

How are the financial statements and the Balanced Scorecard linked? Let's briefly review each viewpoints. Based on the content of the viewpoints, we want to point out where and how the relationship between the financial statements and the BSC can be observed.

The key point of the financial perspective is the following: How do the owners judge the position of the company? Indicators of the financial perspective express how the strategy 
and its implementation contribute to the financial position of the organization, most often to its profitability. Financial targets are mainly related to profitability, return on assets or increase in sales. Here, there are classic financial indicators such as sales, costs, profit, working capital. All of these indicators appear directly in income statements. However, revenue, cost, and profit are just the starting point. Based on these, a multitude of indicators can be defined. Including but not limited to:

- Sales Growth Rate,

- Operating Profit Margin,

- Incremental Fixed Capital Investment,

- Incremental Working Capital Investment,

- Earnings Before Depreciation, Interest and Taxes,

- Earnings Before Interest and Taxes,

- Return on Investment,

- Return on Assets,

- Return on Sales,

- Return on Equity.

For all indicators, the common feature is that the data needed for the calculation can be found in the financial statements (Tóth and Zéman, 2018).

The key point of the customer perspective is: How do customers judge the performance of the organization? When designing a customer perspective, it is necessary to identify the customers, market segments where the organization wants to compete. Financial goals can only be met by the organization if it produces products or services that enhances customers' value. We are not able to satisfy every customer's needs, so it is advisable to set target values by segment. Thus, the customer aspect basically focuses on the long-term relationship with the customers being fruitful and durable. Based on Kaplan's and Norton's recommendations (Kaplan and Norton 1992), the market share, product range, customer satisfaction, complaints, returns, customer group profitability, retained and new customers, etc. are the related indicators. The balance sheet shows customers, and customers can be evaluated (eg notes). Analytical records behind the financial statements include, among others, the number of old and new customers, and the profitability of customers / customer groups. At the same time, we do not receive information on market share or customer satisfaction. That is, financial statements and traditional financial indicators appear in the customer's perspective of the BSC, but they cannot fill the customer's point of view with content alone.

The key issue in the operational process perspective: Which processes should be provided by the organization with an outstanding performance? In this perspective, processes need to be defined where the organization has to deliver outstanding performance in order to meet its financial and customer goals. Earlier approaches focused on existing processes, not those that are relevant to the implementation of the strategy. Another novelty of Norton's and Kaplan's approach is the incorporation of the innovation process into operational processes. Long-term success requires future orientation, future consumer demand mapping, and what (new) products and services will be expected to meet expected needs (Kaplan and Norton, 1996). Includes indicators on supply chain management, organizational innovation, and process regulation. Typical indicators of the operational process perspective are product / service quality, efficiency, lead times. Financial accounting can only partially trace the organizational processes and thus the production processes. Accounting is suitable for tracking resource usage (cost accounting). Partially suitable for monitoring quality processes (eg scrap, scrapping). However, these capabilities in the accounting system only cover a few indicators. Financial accounting can therefore typically only support the BSC indirectly. 
The key question of the learning and development perspective: How can the ability to develop and change be preserved? The learning and development perspective creates the backdrop to the success of the previous three perspectives. The short-term financial approach can easily result in the organization not paying enough attention to its employees, employees' capabilities, and information system. The organization can only achieve its strategic goals if it invests in people (trainings), systems (information systems) and procedures (information technology) and encourages its employees to work in line with organizational goals. So the three pillars of the viewpoint are:

- Employee skills,

- Information system capabilities,

- Consistency of motivation, authority, individual and organizational goals.

Measuring employee skills and motivating is not a classic accounting task. Financial accounting - like the previous point of view - can only support this viewpoint by building on the database of analytical records. For example, the simplest, most common indicator of productivity is the revenue per employee or to measure employee retention, most often the (key) fluctuation rate is quantified.

\subsection{Financial indicators complementing supporting methods of strategic decision making}

Another utilization of financial indicators is if they are not taken into account in themselves but are complemented by or combined with systems supporting strategic decision making. Nowadays several support systems exist that foster strategic decision making. Their categorization may be carried out as follows: on the basis of the aim of use (status analysis, strategic directions and goals, strategy execution, strategy follow-up); on the basis of the level of business environment analyzed (micro-, industrial market-, macro), on the basis of the entities status vs. analyzed environment or rather of the potential influence (tools analyzing internal and external environment) and also on the basis of the complexity of the methods applied (simple and complex systems).

Regarding strategic management and strategic decision making in a process approach, Laáb (2012) distinguishes four steps:

1. Situation Analysis: Here we can find assets that support the analysis of micro and macro environment.

2. The second step of the process is the design of strategic directions and goals. Among other things, it is developing future vision, defining strategic directions, as well as outlining the strategic target map.

3. The next step in the process is to break down the above outlined strategic directions. This includes, among other things, breaking down the institutional strategy into strategic actions, defining part and functional strategies, taking into account individual goals and implementing individual performance evaluation.

4. The fourth step of the process although the last one, is not the end of the decision making process, as the preparation of the reports of the top management reports, dashboards, and customer and supplier reports is a complete process, serving as a feedback on the correctness of the decisions.

In order to identify the main characteristics of the companies under investigation, it is necessary to carry out various micro and macro environmental surveys for entities, including:

- PEST (EL) / STEEP model

- Diamond model

- Porter's 5-factor model

- Industry lifecycle model

- Strategy group analysis 
- SWOT analysis.

The most important method for analyzing macroenvironment is the PEST (EL) or STEEP model, which mosaic words have been created to shorten the use of the environmental element in English (Political, Economical, Social, Technological, Enviromental, Legal and Social, Technological, Economical, Ecological, Political)

Although companies have no impact on these factors, the analysis is of paramount importance, as they can help determine the operating framework of companies (Ansoff, 1957; Levitt, 1965).

Among the sector specialities the most relevant is that affect financial indicators and liquidity because without it correct conclusions cannot be concluded (Rastogi and Trivedi, 2010).

The name of the Diamond Model is given because of its graphic appearance. The model is grouped around four factors of the national economy: quality of production factors, the relationship between company strategy and competition, local demand factors, and creation of related and supporting industries (Porter, 1990).

The industry is called a group of companies that produce the same or directly substitutable products/services (Porter, 1979). Mapping the boundaries of the industry contributes to mapping the structure.

An interesting point in the study of a particular group of entities is to answer the question how to interpret competitors in a given industry - for example natural monopolies, should or have to talk about substitute products. In assessing and defining this situation, Porter's 5 -factors (force) model can provide a framework that takes into account the following factors: threat of new entrants, bargaining power of suppliers, threat of substitution products, customer bargaining power, intensity of industry competition. Reflecting on the framework can provide additional information to examine the profitability situation of entities in the industry, as it can provide explaination why certain industries are more profitable than other industries (Porter, 2008).

When analyzing the management of companies the target is to recognize Strategic Groups - companies that broadly follow a similar strategy - as this can help in comparing performances. In the design of strategic groups it is necessary to select classification characteristics of the strategy and to define the methods of group formation, which can be done with the application of two-dimensional nets and multidimensional analysis (Rastogi, Trivedi, 2010).

The biggest influence of the company is related to the microenvironment. The most diverse and colorful tools in this field are not accidentally created and applied:

- SWOT analysis for linking external and internal environmental elements

- (Product) Life-cycle analysis

- Widespread portfolio models for analyzing the market position of business units and products, and formulating strategic recommendations from these:

o Ansoff matrix

o BCG matrix

o GE-McKinsey model

o Hofer model

o Shell matrix

o ADL matrix

- Suitable for identifying corporate capabilities:

o VRIN analysis

o VRIO analysis framework.

SWOT analysis creates a link between external and internal environmental elements. Watkins (2007) stated that this is a method suitable for evaluating external and internal factors together (Watkins, 2007). 
This procedure can be a useful as an organized summary of examinations, e.g. in the context of due diligence, environmental analysis, activities and sub-activities (Porter, 2008). Based the traditional four-factor SWOT analysis - (internal) Strengths, (internal) Weaknesses, (external) Opportunities, (external) Treats - the eight-factor analysis is also increasingly used, which simultaneously characterizes the present and future expected situation. With this analysis the followings will be implemented:

- Alignment of external (macro + micro) environmental factors and internal company characteristics;

- Coordination of the present and future situation;

- Matching results and strategic recommendations (Rastogi, Trivedi, 2010).

Traditional financial indicators calculated from financial statements cannot provide adequate information for the management, do not support strategic decisions. The reason for this is the methodology used in producing financial statements and the operational logic of financial accounting.

\section{Conclusion and further research plan}

The study dealt with two of the relationship between Financial Indicators and Strategic decisions and examined the appearance of financial indicators in BSC (not only in the BSC Financial perspective). Furthermore, the study also analyzed the way how financial indicators complement to the strategic environmental methodology

The specific relationship between financial indicators and support systems of strategic decision making comes from the fact that financial indicators not only complement measurement and analytic tools of environment and strategy but are necessities in an exact and complex analysis of strategy and business environment (good examples are the tools measuring and analyzing business life cycle, product life cycle, industrial trends).

The research has shown, based on the relevant literature and examples, how relevant financial indicators are reflected in the strategic decision-making methods, and provides a good basis for developing industry-based models in the future.

\section{Acknowledgements}

This research was supported by the project no. EFOP-3.6.2-16-2017-00007, titled Aspects on the development of intelligent, sustainable and inclusive society: social, technological, innovation networks in employment and digital economy. The project has been supported by the European Union, co-financed by the European Social Fund and the budget of Hungary.

This article is based on a contribution presented at the 9th Edition of the International Conference of Doctoral Students and Young Researchers "Emerging Markets Economics and Business", Oradea, 21.11.2018, and represents an extended version of it.

\section{References}

Ansoff, I., 1957. Strategies for Diversification, Harvard Business Review, 5, pp. 113-124. Butler, J. B., Henderson, S. C. and Raiborn, C., 2011. Sustainability and the Balanced Scorecard: Integrating Green Measures into Business Reporting, Management Accounting Quarterly, 2.

Demény, A. and Musinszki, Z., 2016. Social Accounting - In the Wake of the Sustainability. Theory Methodology Practice: Club of Economics in Miskolc, 2, pp. 26-40.

Fenyves, V., Bács, Z., Zéman, Z., Böcskei E. and Tarnóczi, T., 2018. The Role of the Notes to the financial statements in corporate decision-making, Corporate ownership and controls, 4, pp. 138-148. 
Hágen, I. Zs. and Borsós, E., 2015. BSC modellel a kereskedelmi tevékenységet végző vállalkozások versenyképességéért, Controller Info, 1, pp. 42-47.

International Accounting Standards Committee (1997) International Accounting Standard 1

Presentation of Financial Statements available at:

https://www.ifrs.org/issued-standards/list-of-standards/ias-1-presentation-of-financial-state ments/ [accessed 18.01.2019].

Kaplan, R. S. and Norton, P. D., 1992. The Balanced Scorecard - Measures that Drive Performance, Harvard Business Review, 1-2, pp. 71-79.

Kaplan, R. S. and Norton, P. D., 1996. Using the Balanced Scorecard as a Strategic Management System, Harvard Business Review, 1-2. pp. 75-85.

Laáb, Á., 2012. Döntéstámogató számvitel, Budapest: Wolters Kluwer.

Levitt, T.,1965. Exploit the Product Life Cycle. Harvard Business Review 6, pp. 81-94.

Maltz, A. C., Shenhar, A. J. and Reilly, R. R., 2003. Beyond the Balanced Scorecard: Refining the Search for Organisational Success Measures. Long Range Planning, 2, pp. 187-204.

Molnár, V., 2016. Nem termelési folyamatok kontrollja SixSigma megközelítésben. Controller Info, 2, pp. 37-44.

Molnár, V. and Tumik, Á., 2017. Várakozási veszteségből adódó költségek LeanSixSigma megközelítésben: egy ABC-alapú döntési modell. Controller Info, 1, pp. 35-40.

Porter, M., 1979. How competitivene forces shape strategy. Harvard Business Review, 2, pp. 137-145.

Porter, M., 1990. The competitve advantage of nations; Harvard Business Review, 2, pp. 73-91.

Porter, M., 2008. The five competitive forces that shape strategy; Harvard Business Review, 1, pp. 25-40.

Rastogi, N. and Trivedi, M. K., 2016. Pestle Technique A Tool To Identify External Risks In Construction Projects. International Research Journal of Engineering and Technology, 1, pp. 384-388.

Tóth, A. and Zéman, Z., 2018. Stratégiai pénzügyi controlling és menedzsment. Budapest: Akadémia Kiadó.

Veresné, S. M., 2013. A szervezeti kompetencia- és képességépítés néhány sajátossága. Controller Info, 11, pp. 21-30.

Watkins, M. D., 2007. Answering a Reader's Strategy Question. Harvard Business Review [online].

available

at:

https://hbr.org/2007/03/from-swot-to-tows-answering-a-readers-strategy-question

[accessed 30 January 2019].

\section{Bio-note}

Zoltán Musinszki, PhD is associate professor and Vice-Dean for Scientific and Accreditation Affairs at the Institute of Finance and Accounting at the University of Miskolc, Hungary. His field of research is management control, management and cost accounting. He is currently researching the evolution and development of controlling and cost systems for small and medium-sized enterprises and their social innovation aspects.

Gábor Béla Süveges, is assistant lecturer in the Institute of Finance and Accounting at the University of Miskolc, Hungary. He is the Vice-President of the Hantos Elemér College for Advanced Studies. His field of research is management accounting. He is currently researching the significant differences the pecuniary, financial and profitability situation of Hungarian district heat suppliers and the social innovations in the field of district heating. 